\title{
Tumbuhan Selasih Dalam al-Quran Dan Hadith: Analisis Terhadap Manfaatnya Berasaskan Kepada Penyelidikan Semasa
}

\author{
Khadher Ahmad $^{1 *}$, Mohd Yakub @ Zulkifli Mohd Yusoff ${ }^{2}$, \\ Khalijah Awang ${ }^{3}$, Rozana Othman ${ }^{4}$, Monika@ Munirah \\ Abd Razzak ${ }^{5}$, \\ Nurulwahidah Fauzi ${ }^{6}$, Mohd Asmadi Yakob ${ }^{7}$, Mohd Farhan \\ Md Ariffin ${ }^{8}$ \\ 1,2,5,8 Jabatan al-Quran dan al-Hadith, Akademi Pengajian Islam, Universiti \\ Malaya, 50603 Kuala Lumpur. \\ ${ }^{3}$ Jabatan Kimia, Fakulti Sains, Universiti Malaya, 50603 Kuala Lumpur. \\ ${ }^{4}$ Jabatan Farmasi, Fakulti Perubatan, Universiti Malaya, 50603 Kuala \\ Lumpur. \\ ${ }^{6}$ Fakulti Pengajian Quran dan Sunnah, Universiti Sains Islam Malaysia, \\ 71800 Nilai. \\ ${ }^{7}$ Akademi Pengajian Islam Kontemporari (ACIS), Universiti Teknologi \\ MARA, Shah Alam, Malaysia \\ * Pengarang Penghubung \\ khadher82@um.edu.my
}

\begin{abstract}
ABSTRAK
Selasih (nama saintifik; Ocimum basilicum Linn.) merupakan khazanah alam semulajadi yang istimewa. Penyebutan tentangnya yang dirakamkan dalam alQuran dan al-Hadith telah menyerlahkan sisi istimewanya. Namun begitu, tidak ramai yang menyedari akan fakta ini. Malah, selasih dianggap tumbuhan yang kurang berharga kerana tidak bernilai komersial. Populariti selasih yang kurang berbanding delima, anggur dan kurma menjadikannya dipandang sepi. Kedangkalan manusia untuk mengenal, mengkaji dan memahami manfaat selasih menjadikannya tidak dikenali, kurang dikaji, tidak diyakini dan jarang digunakan. Oleh itu, kajian ini akan menonjolkan kelebihan dan manfaat yang boleh didapati daripada selasih. Kajian ini menggunapakai keutamaan perincian saintifik dalam menyenarai secara fakta manfaat-manfaat selasih. Dalil daripada al-Quran dan al-Hadith akan menjadi asas bagi menyatakan signifikan selasih daripada perspektif Islam. Kajian ini turut menggunapakai metodologi bibliometrik terhadap selasih. Ini penting bagi memperoleh data yang berautoriti. Hasilnya, didapati majoriti penyelidikan lepas mengenai selasih
\end{abstract}


didominasi oleh artikel jurnal (65.7\%) dan disertasi sarjana (13.1\%). Kajian lepas berkenaan selasih kebanyakannya berkisar tentang perincian saintifik yang meliputi bidang Farmakologi, Bio-Teknologi, Food Science, Parasitologi and Pesticide, Sains Botani, Bio-Perubatan, Bio-Kimia dan Mikrobiologi. Hasil analisis kandungan turut menemui bahawa daun, minyak, biji dan keseluruhan bahagian pokok bahkan ekstrak daripada pokok selasih mempunyai pelbagai manfaat dari sudut kesihatan misalnya antioksida, antibakteria, antimikrob dan penghindar makhluk perosak. Melihatkan potensi sedia ada, lanjutan penyelidikan terhadap selasih penting bagi manfaat Malaysia.

Kata kunci: Selasih; Nas; Manfaat; Corak Penyelidikan; Potensi

\begin{abstract}
Basil (scientific name; Ocimum basilicum Linn.) is nature's special treasure. Recognition of basil in the Quran and Hadith has accentuated its special side. However, there is lack of awareness on this fact. Basil is even perceived as valueless due to its lack of commercial value. Its less popularity compared to pomegranate, grape and dates has made it seen deserted. Human ignorance to know, study and understand basil's benefits had contributed to it being unrecognized, less studied, unconvincing and rerely consumed. Therefore, this study highlights the advantages and benefits of basil based on the scientific facts. Evidences from the Quran and the Hadith were also provided to proove its significance from the Islamic perspective. The study used bibliometric research methodology as it is important to get authoritative data. Findings showed that the majority of past studies on basil were found in journal articles $(65.7 \%)$ and master dissertations (13.1\%). Previous studies on basil mostly revolved around scientific details in areas such as pharmacology, bio-technology, food science, parasitology and pesticide, botanical sciences, bio-medical, bio-chemistry and microbiology. Content analysis of this study found that leaf, oil, seed and the whole parts of basil tree, even extracts from basil tree, have multiple benefits for health such as antioxidant, antibacterial, antimicrobial and pest deterrents. The various potentials of basil could justify the need for further research on the plant to give benefit to Malaysia.
\end{abstract}

Keywords: Basil; Divine Revelation; Benefit; Research Trend; Potential

\title{
1. Pengenalan
}

Selasih (Ocimum basilicum) atau dikenal sebagai al-Rayhan, alRayhanah (Arab) dan Basil (Inggeris) merupakan tumbuhan daripada famili Lamiaceae yang dipercayai berasal daripada India dan kebanyakan 
negara Asia. Selasih merupakan tumbuhan herba yang tumbuh meliar di kawasan terbuka dan lazim ditanam di kampung-kampung bagi tujuan perubatan tradisional. Subjek boleh didapati di negara beriklim tropika dan subtropika, Afrika serta benua Amerika (Muhamad Zakaria Mustafa Ali Mohd, 2010)

Di Malaysia, selasih dikenali dengan pelbagai nama misalnya selasih, selasih hitam, selasih putih, kemangi (Noraida Ariffin, t.t.), rukuruku atau ruku-ruku hitam. Selasih merupakan sejenis tanaman yang tumbuh menegak dengan ketinggian antara $30-90 \mathrm{~cm}$. Batangnya bersegi dan memiliki variasi warna sama ada hijau, ungu atau perang. Daunnya berwarna hijau pekat, tunggal dan berbentuk oval. Bunganya tumbuh di bahagian hujung batang dan dahan pokok. Keseluruhan bahagian pokok selasih memiliki keistimewaan boleh menghasilkan aroma harum (Ibn Qayyim al-Jawziyyah, 2013)

\section{Sorotan Literatur Mengenai Selasih}

Terdapat pelbagai tumbuhan dan herba yang ada dinyatakan di dalam alQuran dan al-Hadith. Dalam hal ini, penyebutan terhadap tumbuhan secara khusus seperti delima, kurma, zaitun, bidara dan anggur banyak terakam dalam nas. Pernyataan mengenainya sudah cukup untuk menonjolkan sisi kelebihan dan keistimewaan sesuatu.

Berdasarkan sorotan, selasih telah dirakamkan Allah SWT dalam surah al-Rahman (55): 12; dan al-Waqi'ah (56): 88-89. Menurut tafsir $f i$ Zilal al-Qur'an karangan Syed Qutb, ayat surah al-Rahman menerangkan Allah SWT telah mempermudahkan kehidupan makhluk-Nya dengan diberikan makanan berupa buah-buahan seperti kurma yang memiliki kelopak mayang berbentuk indah dan buah yang bermanfaat. Begitu juga bijian daripada pohon berdaun dan berbatang serta tumbuhan berbau harum untuk kegunaan manusia dan haiwan (Yasin, As'ad, 2008)

\subsection{Ayat al-Quran Mengenai Selasih}

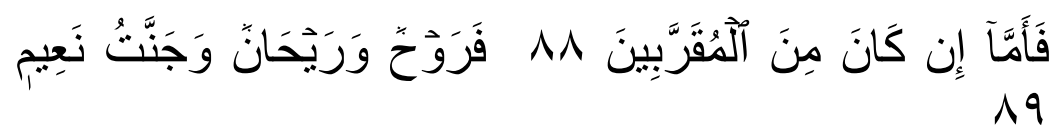

Terjemahan: "Kesudahannya: jika ia (yang mati itu) daripada orang-orang "Muqarrobin". Maka (akan beroleh) kesenangan dan rahmat kesegaran serta syurga kenikmatan." [Surah al-Waqi'ah (56): 88-89] 


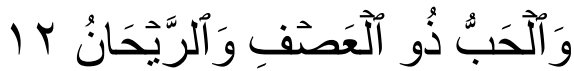

Terjemahan: "Demikian juga terdapat biji-bijian yang ada jerami serta daun, dan terdapat lagi bunga-bungaan yang harum." [Surah al-Rahman (55): 12]

Dalam hal demikian, para ulama telah memberikan tafsiran pelbagai terhadap ayat. Secara umum, ini menunjukkan Allah SWT telah menjadikan tanaman yang berbau harum di muka bumi. Secara spesifik, al-Hasan menyebutkan yang dimaksudkan dengan al-Rayhan adalah semua tumbuhan berbau harum. Dalam erti kata lain, setiap tanaman yang harum dinamakan rayhan.

Menurut tafsir al-Misbah, perkataan rayhan diambil daripada kata ra'ihah yakni aroma. Oleh itu difahami bahawa rayhan merupakan tumbuhan yang memiliki aroma harum seperti ros, yasmin, kemuning dan lain-lain. Di antaranya juga adalah kemangi atau selasih sebagai kurnia Allah SWT. Malah, ada yang memahami maksud rayhan sebagai daun yang hijau sebagai antonim daripada al-'Asf (daun yang kering) (Quraish Shihab, 2002). Dalam konteks kajian, rayhan (selasih) merupakan tumbuhan berbau wangi dan harum yang dikenal dalam kalangan orang Arab sebagai rayhan. Masyarakat Iraq dan Syam pula menamakan habaq dengan rayhan (Ibn Qayyim al-Jawziyyah, 2013; Basyir, 2011)

Tidak memadai dengan nas al-Quran, selasih turut dinyatakan dalam himpunan sabda Nabi Muhammad SAW. Hal demikian ada dirakamkan dalam kitab al-Sahihayn di mana sekaligus menonjolkan lagi sisi istimewa selasih dalam perspektif Islam.

\subsection{Hadith Mengenai Selasih}

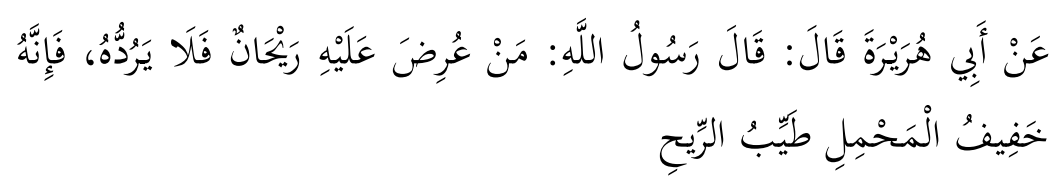

Terjemahan: Diriwayatkan daripada Abu Hurayrah RA, Rasulullah SAW bersabda; "Sesiapa (sahaja) yang diberi rayhan, jangan menolaknya kerana subjek ringan dan berbau harum." [Hadith riwayat Muslim] 


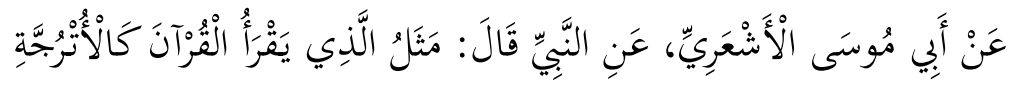

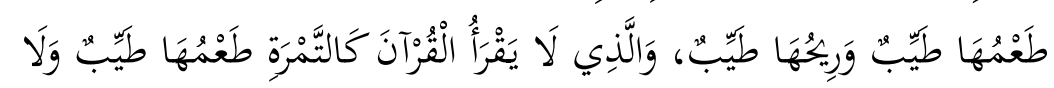

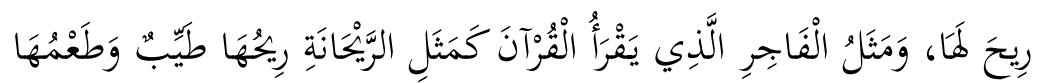

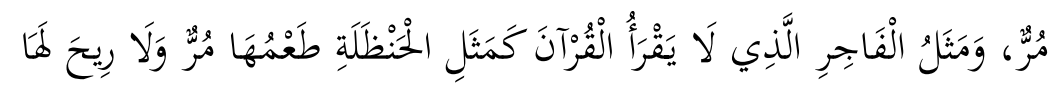

Terjemahan: Diriwayatkan daripada Abu Musa al-Asy'ari RA, daripada Nabi SAW bersabda; "Perumpamaan orang yang membaca al-Quran adalah seperti buah utrujah (lemon), rasanya sedap dan baunya pun harum. Manakala orang yang tidak membaca al-Quran adalah seperti kurma, rasanya sedap tetapi tiada bau. Perumpamaan seorang pendosa yang membaca alQuran pula adalah seperti pohon rayhanah, baunya harum tetapi rasanya pahit. Sedangkan perumpamaan seorang pendosa yang tidak membaca al-Quran adalah seperti peria, rasanya pahit dan tidak juga berbau." [Hadith riwayat al-Bukhari]

Walau bagaimanapun, realiti yang berlaku masa kini jelas kontra dengan ketinggian darjat yang dimiliki selasih. Ini kerana subjek merupakan tumbuhan yang lazim ditanam di halaman atau belakang rumah di Malaysia. Selasih juga dianggap sebagai tumbuhan yang tidak berharga disebabkan tiada nilai komersil. Popularitinya yang kurang dibandingkan buah delima dan anggur menjadikannya jarang diberi perhatian. Kedangkalan manusia untuk memahami manfaat selasih menjadikannya tidak dikenal, kurang dikaji, tidak diyakini dan jarang digunakan (Khadher Ahmad, et al. 2015)

\section{Skop Dan Metodologi}

Makalah ini telah melalui keutamaan perincian saintifik bagi menyatakan secara fakta sekaligus menonjolkan manfaat semulajadi selasih. Dalil daripada al-Quran dan al-Hadith menjadi asas bagi menyatakan kedudukan dan keistimewaan selasih menurut perspektif Islam. Bagi perolehan data yang berautoriti, kajian mempraktikkan analisis bibliometrik dalam menilai dapatan hasil penulisan lepas. Subjek bukan sahaja digunakan dalam bidang sains perpustakaan dan sains maklumat 
tetapi juga digunakan secara meluas dalam bidang lain dalam bentuk analisis kutipan (citation) dan analisis kandungan. Berikut merupakan satu kaedah untuk mengkaji dan mengukur teks atau maklumat dalam bahan penerbitan bagi menonjolkan aspek kajian yang lebih berkesan.

Dalam pada itu, kajian bibliometrik digunakan sebagai penunjuk produktiviti penyelidikan, arah aliran dan penekanan yang diberikan kepada penyelidikan dalam pelbagai disiplin. Kajian ini dapat menentukan keutamaan penyelidikan. Artikel yang diterbitkan dalam mana-mana wacana lazimnya hasil penyelidikan atau kajian terkini yang dapat dikembangkan, diedar untuk dikongsi bersama dan dijadikan rujukan saintifik yang dipercayai. Ini disebabkan proses penerbitan bahan ilmiah perlu melalui proses penyaringan dan pengulasan oleh pakar dalam bidang berkenaan bagi memastikan bahan yang diterbitkan, bukan sahaja mematuhi ciri-ciri untuk penerbitan jurnal atau bahan ilmiah tetapi turut memastikan penyelidikan yang dijalankan mengikut tatacara sepatutnya (Raihanah \& Asmak, 2009).

Dalam konteks ini, metodologi yang betul adalah penting bagi memastikan setiap data yang ingin dicapai dapat dijumpai. Dari sudut pengumpulan data, pencarian ditumpukan terhadap bahan ilmiah seperti tesis $\mathrm{PhD}$, disertasi sarjana, bab dalam buku, buku akademik, artikel jurnal dan sebagainya mengguna pakai kemudahan perpustakaan dan rujukan atas talian seperti mendeley, research gate, academia, google scholar, science direct dan lain-lain. Selepas dikumpulkan, semua data diimbas dan dijadualkan mengikut bahagian. Subjek seterusnya dianalisa mengguna pakai program statistik SPSS (Statistical Package for the Social Sciences) versi 6.0.

\section{Perbincangan Deskriptif Kajian}

Merujuk jenis penerbitan berhubung selasih, penyelidikan lepas boleh dibahagikan kepada 7 item. Berikut merupakan hasil perbincangan kajian: 
Rajah 1: Bahan Penerbitan Berkaitan Selasih

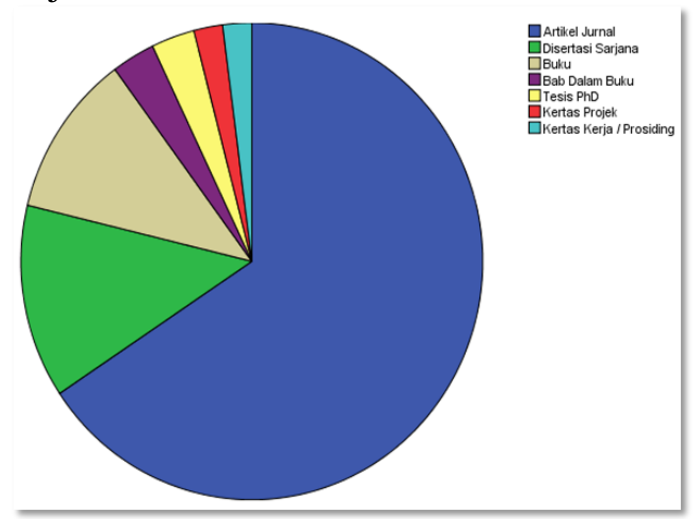

Sumber: Analisis Pengkaji

Merujuk rajah di atas, daripada 121 item penerbitan berkaitan, didapati majoriti bahan penyelidikan lepas mengenai selasih didominasi oleh bahan penerbitan jenis artikel jurnal sebanyak 65.7\%. Peratusan kedua tertinggi pula disertasi sarjana sebanyak $13.1 \%$. Ini diikuti buku (11.1\%), bab dalam buku (3.0\%) dan tesis $\mathrm{PhD}$ (3.0). Peratusan terendah dicatatkan kertas projek (latihan ilmiah) dan kertas kerja/prosiding dengan peratusan yang sama sebanyak $2.0 \%$.

Rajah 2: Bidang Penyelidikan Berhubung Selasih

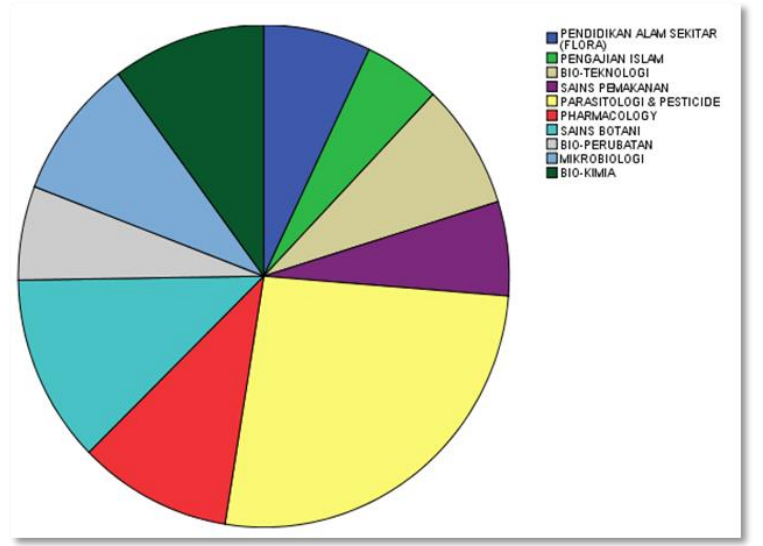

Sumber: Analisis Pengkaji

Melihatkan metode analisis yang pernah dilakukan terhadap 
selasih, penyelidikan lepas kebanyakan berkisar tentang kajian sains. Justifikasinya, bagi kajian sains mengenai selasih sahaja telah terbahagi kepada lapan skop bidang. Fokus perbincangan saintifik terhadap selasih adalah meliputi bidang Farmakologi, Bio-Teknologi, Food Science, Parasitologi and Pesticide, Sains Botani, Bio-Perubatan, Bio-Kimia dan Mikrobiologi. Hanya satu bidang yang memfokuskan analisis berasaskan pengajian Islam. Tambahan bidang Pendidikan Alam Sekitar (Flora) turut dimuatkan bagi mengumpulkan hasil kajian bersifat umum mengenai selasih.

Dinilai dari sudut jumlah penyelidikan, sebanyak 87 jenis bahan melibatkan kajian saintifik berbanding hanya 5 berasaskan pengajian Islam dan 7 pendidikan alam sekitar. Ini membuktikan kajian saintifik terhadap selasih adalah sedia banyak. Secara spesifik, kajian saintifik berhubung selasih dalam bidang Parasitologi and Pesticide mencatatkan peratusan tertinggi terutama melibatkan penggunaan minyak pati selasih dan kemangi dalam menangani ancaman parasit, nyamuk Aedes, nyamuk Anopheles aconitus, lalat dan lalat buah kepada industri ikan jemuran dan penanaman pokok tomato, cabai merah, mangga dan jambu.

Dalam perspektif pengajian Islam, jelas menunjukkan kekurangan bahan penyelidikan khusus membabitkan selasih. Justfikasinya, kajian agamawan mengenai selasih adalah berbentuk umum atau hanya diselitkan kegunaan atau khasiat selasih dalam buku-buku atau artikel jurnal memfokuskan kajian perubatan berasaskan Tibb al-Nabawi mahupun makanan sunnah menurut al-Quran dan al-Hadith. Antara contoh terbaik adalah buku Tibb al-Nabawi hasil sumbangan Ibn Qayyim al-Jawziyyah (2013).

Hasilnya, selasih merupakan sejenis tumbuhan yang telah menarik perhatian penyelidik daripada seluruh dunia. Malah, terdapat pelbagai penyelidikan berhubung selasih telah dilakukan terutama daripada negara jiran, Indonesia. Demikian, langkah ini wajar diikuti penyelidik Malaysia. Hal ini kerana semua bahan berasal daripada selasih tersebut mempunyai signifikan bagi tujuan analisis lanjutan oleh para penyelidik. Ini termasuk semua bahagian pokok selasih termasuk bijinya yang mampu dimanfaatkan bagi menghasilkan ekstrak-ekstrak berguna.

\section{Dapatan Analisis Kandungan}

Setelah daripada pengumpulan bahan-bahan penerbitan berhubung selasih, dilakukan analisis kandungan secara rinci bagi menampilkan 
manfaat yang terdapat pada selasih. Hasil analisis kandungan adalah berikut:

Pembuktian Manfaat Selasih Dalam Perspektif Saintifik

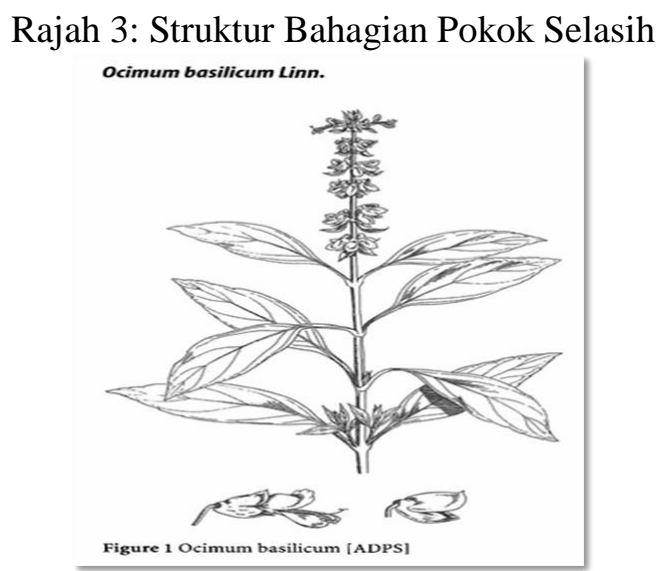

Sumber: Nurcahyanti, Agustina, 2011

Selasih atau nama saintifiknya Ocimum basilicum Linn. merupakan salah satu daripada spesies tumbuhan yang umumnya dikenal sebagai basil. Terdapat lebih kurang 150 spesies tumbuhan daripada gen Ocimum dan spesies basilicum merupakan antara yang paling penting. Nama genus Ocimum bererti tanaman memiliki aroma khas daripada daun. Subjek diketahui mempunyai pelbagai manfaat, aroma yang kuat dan ditanam bagi menghasilkan minyak pati (Muhamad Zakaria Mustafa Ali Mohd, 2010). Selasih merupakan tumbuhan berasal daripada India dan banyak ditanam di Suriname. Ia berhubungan rapat dengan kemangi (Nurcahyanti, Agustina, 2011).

Dalam pada itu, terdapat persamaan antara nama-nama herba yang terdapat di Malaysia dan India. Antaranya adalah Basil (Ocimum basilicum), Telasih, Selasi, Selasep, Sulasi (Sanskr. Tulasi, Tulashi); Pomegranate (Punicagranatum) Dalima, Selasih, Dalimo, Talima (Sanskr. Delum); Indian Jujube (Zizyphus mauritiana) Bidara, Dara, Widara (Sanskr. Badari, Badara). Justifikasinya, persamaan ini tidak berlaku secara kebetulan, bahkan rekod sejarah menyatakan herba-herba ini telah dipindahkan dan ditanam sewaktu zaman Srivijaya dan Majapahit berdasarkan istilah-istilah yang diambil daripada bahasa Sanskrit (E.D Merril, 1942). 
Di samping itu, spesies lain bagi kumpulan selasih adalah kemangi yang merupakan anggota famili Lamiaceae, yang bererti kelompok tanaman dengan bunga berbibir. Tanaman tersebut juga mempunyai hubungan kekeluargaan dengan daun mint (Mentha arvensis), yang dikenal orang Sunda sebagai karesmen, yang lazimnya dikunyah atau dimakan mentah. Antara keluarga kemangi juga adalah daun bangunbangun atau daun jinten (Coleus amboinicus) (Van Steenis, 2006).

Merujuk perihal kemangi, subjek dalam taksonomi tanaman tergolong dalam keluarga Ocimum yang terdiri daripada 50-150 jenis yang tersebar di benua Asia, Afrika sehingga Amerika Tengah dan Selatan. Daripada semua Ocimum tersebut, hanya beberapa spesies menjadi komoditi komersial, di antaranya jenis Ocimum americanum, Ocimum sanctum, Ocimum gratissimum, Ocimum basillicum dan beberapa spesies lain (Undang Ahmad Dasuki, 1991).

Lebih utama dan unik, selasih sangat kaya dengan aroma dan ini telah menarik ramai pengkaji untuk meneliti apakah kandungan yang wujud di dalamnya (Simon, J.E., M.R. Morales, W. B. Phippen, R.F. Vieira, Z. Hao, 1999). Demikian didapati sebatian kimia yang terdapat dalam selasih adalah seperti linalool (James E. Simon, Mario R. Morales, Winthrop B. Phippen, Roberto Fontes Vieira, Zhigang Hao, 1999), eugenol (berguna mengubati asma, batuk, mengawal aliran cecair mukus berlebihan) (Johnson, CB; Kirby, J; Naxakis, G; Pearson, S., 1999), limonena, tau-kadinol, eukaliptol dan germakrena.

Berikut merupakan struktur kimia beberapa sebatian di dalam selasih:<smiles>C=CC(C)(O)CCC=C(C)C</smiles>

Linalool<smiles>C=CCc1ccc(O)c(OC)c1</smiles>

Eugenol<smiles>C=C(C)[C@H]1CC=C(C)CC1</smiles>

Limonena

Seterusnya, kandungan kimia selasih turut mengandungi ocimene, careen, methylchavicol, eugenol, eugenol metil eter, anethole, metil cinnamate, 3-hexen-1-ol, 3-octanone, flanoviod (Diah Dhianawaty, Ramdan Panigoro, Samsudin Surialaga, Pricilla Purushothman, 2012) dan furfural (H. Arief Hariana, t.t.). 
Berdasarkan kajian lain terhadap selasih, didapati dalam 100 gram daun selasih mengandungi $3.3 \mathrm{~g}$ protein, $1.2 \mathrm{~g}$ lemak, $7 \mathrm{~g}$ karbohidrat, $2 \mathrm{~g}$ serat, $320 \mathrm{mg}$ kalsium, $33 \mathrm{mg}$ fosforus, $4.8 \mathrm{mg}$ besi, $12 \mathrm{mg}$ natrium, 429 $\mathrm{mg}$ potassium, $86.5 \mathrm{~g}$ air, $4500 \mathrm{mcg}$ beta-karoten ekuivalen, $0.08 \mathrm{mg}$ tiamin, $0.35 \mathrm{mg}$ riboflavin, $0.8 \mathrm{mg}$ niacin dan $27 \mathrm{~g}$ vitamin C. Walau bagaimanapun, daun dan biji selasih tidak boleh menjadi sumber utama untuk memenuhi keperluan tubuh badan disebabkan kandungan zat gizinya yang sangat rendah (Ali Khomsan, 2009).

Selain daripada itu, beberapa jenis tumbuhan khususnya daripada keluarga Lamiaceae seperti selasih, sage, oregano dan thyme dijumpai mempunyai sifat antioksida yang tinggi. Berdasarkan penyelidikan, ekstrak biji selasih boleh merencatkan pertumbuhan bakteria (Alfia Fajarina Rahmawati, Rindy Widya Rasmono, Shara Garluci, 2010). Ini sejajar dengan penelitian Ntezurubanza (1984) dan Singh et.al.(2007) yang melaporkan selasih bersifat antimikrob dan antibakteria. Subjek mampu melawan bakteria Mycobacterium tuberculosis, Staphylococcus aureus in vitro, Bacillus purnilus dan Pseudomonas aeruginosa (Alfia Fajarina Rahmawati, Rindy Widya Rasmono, Shara Garluci, 2010).

Dalam pada itu, minyak pati selasih dan kemangi (Rubiati Rahayu, 2014) mampu menghindarkan ancaman lalat buah (sebagai insect ovipositing repellent) (Deni Pranowo, Teguh Apriyanto, Tutik Dwi Wahyuningsih, Suputa, 2011). Antara spesies lalat buah yang sensitif terhadap ekstrak selasih ungu dan selasih hijau ialah $B$. dorsalis, $B$. carambola, B. papayae, B. umbrosus. Manakala jumlah lalat buah yang paling banyak terperangkap oleh ekstrak selasih ungu dan selasih hijau adalah B. Dorsalis. Masa efektif untuk memerangkap imago lalat buah menggunakan ekstrak selasih hijau pula adalah antara 24-28 hari manakala ekstrak selasih ungu adalah antara 25-29 hari (Yulia Pujiastuti, Triani Adam, 2009). Kajian terhadap fungsi selasih dalam menangani ancaman lalat buah pada buah mangga, cabai merah (Ir. Sutjipto, MS, Ir. Sigit Prastowo, MP, Ir. M. Wildan Jadmiko, MP, 2007; Ervin Siwi Arti, 2011; Umi Saidah, 2011; Rina Dwi Hartanti, 2014), jambu (Lailatul Qodariyah, 2011) dan tomato (Agustinus Artanto, 2009) adalah antara yang lazim dilakukan.

Hasil penelitian lain turut mendapati kandungan metil eugenol yang terdapat dalam ekstrak daun dan bunga selasih (Ocimum sanctum L.) mampu memberi kesan terhadap perbezaan jumlah lalat buah jantan (Bactrocera $s p$ ). Konsentrasi ekstrak daun dan bunga selasih yang paling efektif menarik lalat buah adalah pada $75 \%$ dengan jumlah lalat buah jantan pada ekstrak daun sebanyak 110 helai dan ekstrak bunga sebanyak 
170 kuntum. Ini didorong bahagian pokok selasih khususnya pada daun dan bunga mengandungi senyawa metil eugenol yang merupakan foodlure yang diperlukan oleh lalat buah jantan (Bactrocera sp.) untuk dimakan (Agung Rohati Amalia, 2007).

Manakala jika diuji potensi minyak pati daun selasih ungu (Ocimum sanctum) terhadap lalat rumah (Musca domestica), didapati konsentrasi minyak pati daun selasih ungu sebanyak $20 \%$ paling memberikan hasil terbaik daripada konsentrasi ujikaji yang lain (iaitu $2.5 \%, 5 \%, 10 \%$ dan secara terkawal). Keberkesanannya boleh dilihat daripada jumlah kematian larva tertinggi (52\%), kemampuan eksidis terendah (48\%) dan kemampuan eklosi yang rendah (20\%) (Fitriana, 2014; Dattu Iffah Hanidhar, 2007).

Di samping itu, selasih mengandungi methyleugenol dan metylchavicol yang berfungsi sebagai insektisida, zat penolak makan (antifeeding) untuk mengendalikan larva nyamuk dan atraktan. Daripada penelitian, diketahui terdapat pengaruh yang baik oleh ekstrak daun selasih terhadap umur dan jumlah kematian larva dan pupa nyamuk Aedes aegypti L (Salima Musbiyana, 2004). Oleh demikian, daun selasih (Ocimum gratissimum L.) boleh digunakan sebagai bahan alternatif (Anneke Fauziyah Ali, 2012) bagi tujuan pengendalian larva nyamuk Aedes aegypti L. daripada jenis tumbuhan yang lain (Meilina Yuhanita Dewi, Koerniasari dan Irwan Sulistyo, 2013) selain murah, mudah dihasilkan serta tidak membahayakan manusia, haiwan dan persekitaran (I. Putu Gede Yudhi Arjentinia, 2001). Di Amerika Syarikat, ekstrak selasih diformulasikan sebagai insektisida semprot dan ubat nyamuk (Salima Musbiyana, 2004).

Dalam satu kajian lain, daya hindar minyak pati selasih terhadap gangguan nyamuk Anopheles aconitus yang dilakukan dengan ujikaji berasaskan Post test only control group design telah diuji. Hasil kajian mendapati terdapat perbezaan purata jumlah nyamuk Anopheles aconitus yang menempel pada lengan yang telah disapu dengan minyak pati selasih pada pelbagai dos. Dos paling efektif ialah pada $0.3 \mathrm{ml}$ dan mampu menghindari gangguan nyamuk lebih daripada 80\% (Handayani, Risqa Wahyu Handayani, 2005). Pertumbuhan larva juga menurun dengan meningkatnya konsentrasi ekstrak daun selasih, nilai GI (Growth index) berkisar antara 1-0 dan nilai RGI (Relative growth index) berkisar antara 100-81\% (Istimuyasaroh, Mochamad Hadi, Udi Tarwotjo, 2009).

Dalam pengubatan tradisional, selasih berupaya digunakan bagi merangsang penyerapan dan pengeluaran peluh, pelawas kencing, melancarkan peredaran darah, melegakan sakit dan membersihkan racun. 
Biji selasih boleh berfungsi sebagai ubat bagi masalah radang mata (corneal opacity) (Drs. H. Arief Hariana, t.t.). Air rebusan selasih digunakan bagi merawat batuk. Air minuman selasih diamalkan oleh wanita bersalin dan orang yang mengalami gatal-gatal tekak. Pengambilan air biji selasih sekali sehari juga boleh menghilangkan sakit kepala (Muhamad Zakaria Mustafa Ali Mohd, 2010). Selain daripada itu, daun selasih digunakan dalam rawatan cirit birit dan kegagalan buah pinggang (Klimankova, Eva, Kateřina Holadová, Jana Hajšlová, Tomáš Čajka, Jan Poustka \& Martin Koudela, 2008). Ekstrak daun selasih pula lazim diaplikasikan bagi menangani sakit gigi, gigitan serangga dan jangkitan cacing pita. Subjek turut digunakan dalam masakan sebagai penambah aroma. Bijinya digunakan dalam minuman dan dapat menghasilkan minyak masakan.

Berhubung kemangi pula, subjek merupakan salah satu tanaman herba yang memiliki aroma harum dalam kalangan al-Rayhan sebagaimana selasih dan mempunyai variasi kegunaan. Daun, batang dan keseluruhan pokoknya juga bersifat multifungsi (Dian Delta, 2014). Di India dan Afrika, kemangi digunakan sebagai teh. Di samping aroma yang kuat, subjek disajikan semasa pertukaran musim bagi mengelakkan masalah kesihatan seperti batuk, selesema dan demam. Di Eropah, minyak pati kemangi diekstrak dan digunakan sebagai bahan campuran ubat atau bahan perawatan tubuh seperti sabun, minyak wangi dan aroma terapi. Aroma minyak pati kemangi hanya hilang selepas 24 jam disapu pada tubuh. Disebabkan ciri unik tersebut, ia diklasifikasikan sebagai minyak pati bernilai tinggi. Minyak pati kemangi kaya dengan pro vitamin A, kalsium dan fosforus (Noraida Ariffin, t.t.). Kandungan kimia di dalamnya juga telah menjadikan kemangi sebagai tanaman herba popular. Dalam "Daftar Komposisi Bahan Makanan" oleh Direktorat Gizi Departemen Gizi Kesehatan Republik Indonesia, setiap 100 gram daun kemangi mengandungi 5000 SI vitamin A. Ia turut mengandungi mineral, kalsium dan fosforus sebanyak 45 dan $75 \mathrm{mg}$ pada setiap 100 gram daun kemangi (Savitri \& Evika Sansi, 2008).

Antara kegunaan kemangi yang dilaporkan adalah merangsang imun tubuh, menurunkan kolesterol, mencegah kemandulan dan ejakulasi pramatang. Kajian khusus terhadap kualiti sperma tikus turut menunjukkan daya hidup spermatozoa tikus lebih tinggi pada tahap konsentrasi ekstrak kemangi tertentu (Aditya Dwi Setyadi, 2006). Di samping iru, satu kajian terhadap ternakan ayam juga mendapati eksrak etanol daun kemangi dapat membantu meningkatkan jumlah pengeluaran dan berat telur ayam (Andiyato et al., 2014). Minyak kemangi turut 
digunakan sebagai bahan pewangi dalam sabun (Dian Anggraini, 2002). Dalam satu kajian lain, daun kemangi dijadikan sebagai alternatif "handsanitizer." Ini diakui dengan keberkesanan minyak pati daun kemangi dalam membunuh bakteria $S$. aureus dan E. coli (Novita Maylia Eka Cahyani, 2014).

Kemangi turut dilaporkan mengandungi alkaloid, triterpenoid, flavonoid, saponin, steroid dan tannin (Nur Atikah, 2013) yang mempunyai sifat antibakteria. Satu kajian pengaruh ekstrak daun kemangi telah dilakukan terhadap eritema dan nanah arnab yang dijangkiti Staphylococcus aureus. Hasil menunjukkan ekstrak daun kemangi memberikan kesan penyembuhan jangkitan lebih cepat daripada kaedah water-soluble base, absorption and washable base (Olivia H. Naibaho, Paulino V. Y. Yamlean \& Weny Wiyono, 2013). Selain itu, daun kemangi terbukti boleh membantu menyembuhkan luka. Permukaan dan panjang luka yang diletakkan daun kemangi lebih cepat mengecil dibandingkan dengan luka yang tidak diletakkan daun kemangi (Nurul Fitri Ramdani \& Christi Mambo, 2014).

Seterusnya, minyak pati kemangi turut berpengaruh terhadap perkembangan larva lalat hijau (Chrysomya megacephala) pada ikan mas (Cyprinus carpio). Lalat hijau merupakan serangga penyebab utama kerosakan produk ikan masin berdaging tebal berikutan infestasi larva lalat hijau ketika proses penjemuran ikan. Daripada penelitian, didapati semua tahap konsentrasi ujikaji (iaitu 2.5\%, 5\%, 10\%, 20\%, 40\%) menggunakan minyak pati kemangi dapat mempengaruhi jumlah lalat yang hinggap pada ikan. Penurunan jumlah lalat yang hinggap dan larvanya menurun seiring dengan peningkatan konsentrasi minyak pati kemangi (Dhiosi Oktavia Afrensi, 2007).

Akhirnya, minyak pati kemangi turut mempunyai kemampuan menghalang pertumbuhan bakteria penyebab masalah gangguan pencernaan pada usus seperti Salmonella typhosa $O$, Salmonella paratyphosa A, Salmonella paratyphosa B, Salmonella paratyphosa C, Salmonella paratyphosa D, Shigella dysentriae, Shigella boydii, Shigella flexneri, Shigella sonnei dan Escherichia coli 6-11 dan Escherichia coli O11. Justeru, kajian lanjutan sedang dilakukan untuk mengenal pasti dos kemangi yang sesuai untuk manusia sebagai ubat dalam bentuk kapsul, tablet atau larutan cecair (Sutiyami \& Siti Nuryani, 2014). 


\section{Cadangan Penyelidikan Lanjutan Terhadap Selasih}

Melalui analisis kandungan terhadap selasih, nyata memperlihatkan potensi kegunaan dan manfaat yang pelbagai. Malah terdapat banyak aspek yang boleh dilakukan penyelidikan terperinci pada masa hadapan sama ada dari aspek agama mahupun saintifik, memandangkan bidang kesihatan berasaskan herba merupakan satu bidang yang luas. Berikut merupakan cadangan bidang dan aspek penyelidikan berkaitan selasih setelah penelitian:

(i) Kajian spesifik selasih dalam perspektif agama adalah sangat kurang. Kebanyakan kajian yang bersifat umum perlu dikhususkan dengan menekankan aspek khasiat selasih yang boleh didapati daripada nas sahih. Hal demikian kerana kewujudan banyak hadith berstatus lemah dijadikan hujah khasiat herba, buah-buahan dan tumbuhan menurut Islam.

(ii) Gabungan penyelidikan mengenai selasih dari sudut pandang agama dan sains perlu dipergiat. Setakat penelitian, tiada bahan penerbitan yang membahaskan selasih secara gabungan agama dan pembuktian saintifik. Hasil usaha ini seterusnya akan membuktikan kebenaran Islam dengan pembuktian daripada penelitian saintifik.

(iii) Penyelidikan mengenai selasih dan kemangi di Malaysia didapati amat kurang. Dari segi manfaat, penelitian terhadap spesies selasih yang terdapat di Malaysia boleh diaplikasikan untuk menghasilkan produk kesihatan Malaysia. Justeru, intipati kandungan selasih perlu diteliti dan diambil kesempatan dari sudut keberkesanannya menghasilkan produk yang bernilai tinggi.

\section{Kesimpulan}

Selasih merupakan item penyelidikan daripada alam yang amat berharga. Manfaat selasih tidak dapat disangkal. Ini sekaligus membuktikan keistimewaan selasih sehingga melayakkannya disebut secara khusus dalam al-Quran dan al-Hadith. Satu fakta yang perlu diberi perhatian ialah keseluruhan pokok selasih dan kemangi mampu memberi manfaat untuk kesihatan dan pencegahan penyakit. 
Daripada dapatan kajian, dilaporkan selasih berpotensi dimanfaatkan sebagai produk makanan, wangian, supplemen kesihatan, bersifat antimikrob, antibakteria, antirepellent, berguna mengatasi ancaman haiwan perosak terhadap tanaman dan mempercepatkan kesembuhan kecederaan luaran.

Sebagai harapan, semua aspek pengkajian berkaitan selasih wajar diteliti secara lebih mendalam oleh ahli akademik sama ada dari aspek agama mahupun saintifik bagi tujuan menilai keabsahan, mencari titik pertemuan dan seterusnya menghasilkan suatu produk kesihatan berasaskan selasih yang berguna kepada semua golongan dalam masyarakat. Lanjutan kajian baru terhadap selasih diyakini berupaya menghasilkan impak positif bagi manfaat di peringkat nasional.

\section{Penghargaan}

Penghargaan ditujukan kepada KPT atas anugerah geran penyelidikan TRGS (TR001A-2014A) bertajuk 'Safe and Health Uses of Fruits and Herbs Mentioned in Al-Quran and Ahadith: An Analysis of Ethnomedicinal Importance in Islamic Products in Malaysia'.

\section{Rujukan}

Aditya Dwi Setyadi, 2006, Organ Reproduksi Dan Kualitas Sperma Mencit (mus musculus) Yang Mendapat Pakan Tambahan Kemangi (Ocimum basilicum) Segar, Tesis Sarjana, Program Studi Teknologi Produksi Ternak, Fakultas Peternakan, Institut Pertanian Bogor, Bogor, i-ii.

Agung Rohati Amalia, 2007, Pengaruh Perbedaan Konsentrasi Ekstrak Daun Dan Bunga Selasih (Ocimum Sanctum L.) Terhadap Jumlah Lalat Buah (Bacterocera sp) Yang Masuk Ke Dalam Perangkap Feromon, Department of Biology, Universitas Muhammadiyah Malang, i.

Agustinus Artanto, 2009, Pengaruh Minyak Sereh Dan Minyak Selasih Terhadap Jumlah Lalat Buah Bacterocera dorsalias Hand. Yang Tertangkap Pada Tanaman Tomat, Skripsi Sarjana, Universitas ATMA JAYA Yogyakarta, Fakultas Teknobiologi, Program Studi Biologi, Yogyakarta, 27-33.

Alfia Fajarina Rahmawati, Rindy Widya Rasmono, Shara Garluci, 2010, Ujibioaktivitas Senyawaan Antibakterikalus Daun Selasih (Ocinum 
gratissimum L. forma caryophyllatum) Secara Bioautografi Terhadap Escherichia Coli Dan Staphylococcus aureus, Jurnal Saintifika Gadjah Mada, II (2).

Ali Khomsan, 2009, Rahasia Sehat Dengan Makanan Berkhasiat, Jakarta: Penerbit Buku Kompas, 261.

Andiyato, et.al. 2014, Peningkatan Produktivitas Ayam Petelur Melalui Pemberian Ekstrak Etanol Daun Kemangi, Jurnal Veteriner, 15 (2), 281-287.

Anneke Fauziyah Ali, 2012, Efek Penolak Serangga (Insect Repellent) Ekstrak Etanol Daun Selasih (Ocimum basilicum L.) Terhadap Nyamuk Aedes aegypti L., Indonesia: Universitas Surabaya.

Dattu Iffah Hanidhar, 2007, Pengaruh Pemberian Ekstrak Kemangi (Ocimum basilicum forma citratum) Terhadap Perkembangan Larva Lalat Rumah (Musca domestica), Skripsi Kedokteran Hewan, Fakultas Kedokteran Hewan, Institut Pertanian Bogor, Indonesia, 1927.

Deni Pranowo, Teguh Apriyanto, Tutik Dwi Wahyuningsih, Suputa, 2011, Pemanfaatan Ekstrak Daun Tembakau Dan Daun Selasih Sebagai Insect Ovipositing Repellent Terhadap Lalat Buah (Bacterocera carambolae), Prosiding Seminar Nasional Kimia Dan Pendidikan Kimia III (SN-KPK III), Program Studi Pendidikan Kimia Jurusan PMIPA, Fakultas Keguruan dan Ilmu Pendidikan Universitas Sebelas Maret Surakata di Surakata-Jawa Tengah pada 7 Mei 2011, 496-504.

Dhiosi Oktavia Afrensi, 2007, Pengaruh Minyak Atsiri Kemangi (Ocimum basilicum forma citratum Back) Terhadap Infestasi Larva Lalat Hijau (Chrysomya megacephala) Pada Ikan Mas (Cyprinus carpio), Tesis Sarjana Kedokteran Hewa, Departemen ilmu Penyakit Hewan Dan Kesehatan Masyarakat Veteriner, Fakultas Kedokteran Hewan, Institut Pertanian Bogor, Bogor, 20-21.

Diah Dhianawaty, Ramdan Panigoro, Samsudin Surialaga, Pricilla Purushothman, 2012, Metode Cepat Identifikasi Flanovoid Dari Daun Ocimum Sanctum L. (Selasih), Bandung Medical Journal MKB, 44 (1), 32-37.

Dian Anggraini, 2002, Ekstraksi Dan Pemanfaatan Minyak Daun Kemangi (Ocimum basilicum) Sebagai Bahan Pewangi Pada Sabun Cuci Tangan Cair, Skripsi Sarjana, Fakultas Teknologi Pertanian, Institut Pertanian Bogor, Bogor, 33.

Dian Delta, 2014, Aktivitas Antioksidan Ekstrak Methanol Dan Kloroform Batang Dan Daun Kemangi (Ocimum basilicum L.), Tesis 
Tumbuhan Selasih dalam al-Qur'an dan Hadith

Sarjana Kedokteran, Yogyakarta: Universitas Gadjah Mada, Indonesia, 58-63.

E.D Merril, "The Vegetation of Malaysia" dalam The Far Eastern Quarterly, 2 (1), 74-75.

Ervin Siwi Arti, 2011, Efektivitas Tanaman Selasih (Ocimum basilicum Linn.) Sebagai Atraktan Pengalihan Lalat Buah (Bactrocera sp.) Dalam Merusak Buah Cabai Merah (Capsicum annum L.), Skripsi Sarjana, Program Studi Pendidikan Biologi, Jurusan Pendidikan MIPA, Fakultas Keguruan Dan Ilmu Pendidikan Universitas Jember, Indonesia, 123.

Fitriana, 2014, Uji Potensi minyak Atsiri Daun Selasih Ungu (Ocimum sanctum) Sebagai Insektisisda Nabati Terhadap Terhadap Perkembangan Lalat Rumah (Musca domestica) di Laboratorium, Tesis Sarjana Program Studi Biologi, Yogyakarta: Fakultas Sains Dan Teknologi, xvi.

H. Arief Hariana, t.t., Tumbuhan Obat Dan Khasiatnya Seri 3, Jakarta: Penebar Swadaya, 50.

Handayani, Risqa Wahyu Handayani, 2005, Daya Tolak (Repellency) Minyak Atsiri Selasih (Ocimum Basilicum) Terhadap Nyamuk Anopheles Aconitus Di Laboratorium. Undergraduate Thesis, Indonesia: Diponegoro Universiti, 1.

I Putu Gede Yudhi Arjentinia, 2001, Efektifitas Ekstrak Daun Selasih (Ocimum Grastissimum L.) Dan Ekstrak Daun Mimba (Azadirachta Indica A. Juss.), Sebagai Insektisida Nabati Alternatif Pada Nyamuk Aedes Aegypti L., Fakultas Kedokteran Hewan, Indonesia: Institut Pertanian Bogor, 1-2.

Ibn Qayyim al-Jawziyyah, Perubatan Rasullullah, (terj.) Nabilah Abd. Jalil, 2013, Selangor: Al-Hidayah House of Publishers Sdn. Bhd, 395.

Ir. Sutjipto, MS, Ir. Sigit Prastowo, MP, Ir. M. Wildan Jadmiko, MP, 2007, Keandalan Ekstrak Daun Selasih (Ocimum sanctum) Sebagai Insektisida Nabati Untuk Pengendalian Lalat Buah (Bacterocera dorsalis) Pada Tanaman Cabai Merah (Capsicum annum L., Laporan Penelitian Hibah Bersaing XIV/2 Perguruan Tinggi Tahun Anggaran 2007, Indonesia: Fakultas Pertanian Universitas Jember, ii.

Istimuyasaroh, Mochamad Hadi, Udi Tarwotjo, 2009, Mortalitas Dan Pertumbuhan Larva Nyamuk Anopheles aconitus Kerena Pemberian Ekstrak Daun Selasih (Oscimum basilicum), BIOMA, 11 (2), 59-63.

Lailatul Qodariyah, 2011, Efektivitas Sticky Trap Dan Atraktan Nabati Dari Minyak Selasih (Ocimum basilicum L.) Untuk Pengendalian Hama Lalat Buah (Bactrocera spp.) Pada Tanaman Jambu Biji 
(Psidium guajava L.), Skripsi Sarjana, Program Studi Pendidikan Biologi, Jurusan Pendidikan MIPA, Fakultas Keguruan Dan Ilmu Pendidikan, Universitas Jember, Indonesia, viii-ix.

Meilina Yuhanita Dewi, Koerniasari dan Irwan Sulistyo, 2013, Perbedaan Kemampuan Daya Tolak Minyak Atsiri Bunga Melati (Jasminum sambac) Dan Daun Selasih (Ocimum basilicum) Sebagai Repelen Nyamuk Aedes aegypti, X (1), 31-39.

Muhamad Zakaria Mustafa Ali Mohd, 2010, Traditional Malay Medicinal Plants, Kuala Lumpur: Institut Terjemahan Negara Malaysia Berhad, 89.

Noraida Ariffin, t.t. Penyembuhan Semulajadi Dengan Herba, Malaysia: PTS Millenia, 113-114.

Novita Maylia Eka Cahyani, 2014, Daun Kemangi (Ocimum Cannum) Sebagai Alternatif Pembuatan Handsanitizier, Jurnal Kesehatan Masyarakat (KEMAS), 9 (2), 16-142.

Nur Atikah, 2013, Uji Aktivitas Antimikroba Ekstrak Herba Kemangi (Ocimum americanum L.) Terhadap Staphylococcus aureus dan Candida albicans, Skripsi Sarjana, Fakultas Kedokteran Dan Ilmu Kesihatan, Program Studi Farmasi, Jakarta, vi-vii.

Nurcahyanti, Agustina, 2011. Aktivitas Antioksidan dan Antibakteri Ekstrak Polar dan Non Polar Biji Selasih (Ocimum sanctum Linn). Jurnal Teknologi dan Industri Pangan 22 (1), 5.

Nurul Fitri Ramdani, Christi Mambo, 2014, Uji Efek Daun Kemangi (Ocimum Basilicum L.) Terhadap Penyembuhan Luka Insisi Pada Kelinci (Oryctolagus Cuniculus), Jurnal e-Biomedik PAAI, 2 (1), 1.

Olivia H. Naibaho, Paulino V. Y. Yamlean, Weny Wiyono, 2013. Pengaruh Basis Salep Terhadap Formulasi Sediaan Salep Ekstrak Daun Kemangi (Ocimum santum L.) Pada Kulit Punggung Kelinci Yang Dibuat Infeksi Staphylococcus aureus, Jurnal Ilmiah FarmasiUNSRAT (PHARMACON), 2 (2), 27-34.

Quraish Shihab, 2002, Tafsir Al-Misbah: Pesan, Kesan, dan Keserasian al-Qur'an. Jakarta: Lentera Hati, 502.

Rina Dwi Hartanti, 2014, Potensi Daun Selasih (Ocimum sanctum L.) Sebagai Atraktan Lalat Buah (Bactrocera spp.) Pada Pertanaman Cabai Merah, Skripsi Sarjana, Fakultas Pertanian, Universitas Jember, Indonesia, iii.

Rubiati Rahayu, 2014, Uji Potensi Minyak Atsiri Daun Kemangi (Ocimum basilicum L.) Sebagai Insektisida Nabati Terhadap Lalat Buah (Bactrocera carambolae), Skripsi Sarjana, Program Studi 
Biologi, Fakultas Sains Dan Teknologi, UIN Sunan Kalijaga, Yogyakarta, $\mathrm{x}$.

Salima Musbiyana, 2004, Pengaruh Daun Selasih (Ocimum basilicum L) Sebagai Repelen Terhadap Nyamuk Aedes aegypti L., Disertasi Sarjana, Institut Pertanian Bogor: Fakultas Kedokteran Hewan, 34.

Savitri, Evika Sansi, 2008, Rahasia Tumbuhan Berkhasiat Obat Perspektif Islam. Malang: UIN Press.

Sutiyami, Siti Nuryani, 2014, Uji Aktivitas Minyak Atsiri Kemangi (Ocimum sanctum L.) Pada Berbagai Kuman Penyebab Diare, Jurnal Teknologi Kesehatan, 10 (1), 12-16.

Umi Saidah, 2011, Pengaruh Pola Distribusi Spasial Sistem Tanam Cabai Merah (Capsinum annum L.) Dan Selasih (Ocinum basilicum Linn.) Terhadap Oviposisi Lalat Buah (Bactrocera sp.) Dan Tingkat Kerusakan Buah, Skripsi Sarjana, Program Studi Pendidikan Biologi, Jurusan Pendidikan MIPA, Fakultas Keguruan Dan Ilmu Pendidikan, Universiti Jember, Indonesia, 55.

Undang Ahmad Dasuki, 1991. Sistematik Tumbuhan Tinggi, Bandung:Institut Teknlogi Bandung, 137.

Van Steenis, 2006, Mountain Flora of Java, Brill: Leiden, 145.

Yasin, As'ad, 2008, Tafsir Fi Zilal al-Qur'an. Jakarta: Gema Insani.

Yulia Pujiastuti, Triani Adam, 2009, Keandalan Minyak Selasih (Ocimum sp.). Dalam Mengendalikan Lalat Buah (Diptera: Tephritidae), AGRITROP, 28 (3), 139-146. 